\title{
METODE KUANTITATIF DALAM TEOLOGI PRAKTIS ${ }^{1}$
}

\section{Handi Hadiwitanto"}

\begin{abstract}
One of modern practical theology's task is what so-called descriptive-empirical task. In this sense practical theology does require an empirical approach for her reflection. Therefore practical theologians should have sufficient skills in using methods of field research. Traditionally qualitative methods have been known more among theologians. And in the same time some people suspect that quantitative methods are not suitable and cannot explain any theological problems. Some others concern and think that quantitative methods only work deductively and it is against the tradition of theology from below which normally works inductively. This essay would like to show how quantitative methods can work within theological field and give theologians an alternative approach when they want to empirically understand particular religious community. Obviously we realise that social sciences such as sociology and social psychology have developed quantitative methods in their researches for long time. In the spirit of interdisciplinary approach we owe them some explanations in running particular quantitative analyses.
\end{abstract}

Keywords: quantitative method, quantitative analysis, practical theology, empirical cycle.

\section{Abstrak}

Satu tugas dari teologi praktis modern saat ini adalah deskriptif-empiris di mana teologi harus memahami situasi lapangan secara empiris. Terkait dengan hal ini teologi praktis memerlukan pendekatan empiris sebelum melakukan refleksi teologisnya. Dan dengan demikian maka

* Dosen biasa bidang Teologi Praktis-Pembangunan Jemaat di Fakultas Teologi Universitas Kristen Duta Wacana, Yogyakarta. Email: handihadiwitanto@staff.ukdw.ac.id

(C) HANDI HADIWITANTO | DOI: 10.21460/gema.2017.21.291

This work is licenced under a Creative Commons Attribution-NonCommercial 4.0 International Licence. 
seorang teolog praktis harus memiliki keterampilan yang memadai dalam menggunakan metode-metode penelitian lapangan. Secara tradisional metode kualitatif sudah dikenal dengan lebih baik di antara para teolog. Dan pada saat yang bersamaan beberapa orang curiga bahwa metode kuantitatif tidak cocok dan tidak dapat menjelaskan permasalahan-permasalahan teologis. Beberapa orang lain berpikir bahwa metode kuantitatif bekerja secara deduktif dan hal tersebut melawan tradisi teologi dari bawah yang semestinya bersifat induktif. Tulisan ini hendak memperlihatkan secara kritis bagaimana metode kuantitatif juga dapat bekerja dalam teologi dan memberikan alternatif pada para teolog ketika mereka hendak memahami suatu komunitas religius secara empiris. Tentu kita menyadari bahwa ilmu-ilmu sosial seperti sosiologi dan psikologi sosial telah lama mengembangkan metode kuantitatif ini dalam penelitian-penelitian yang mereka lakukan. Dalam semangat pendekatan interdisipliner kita berhutang pada mereka tentang bagaimana analisis-analisis kuantitatif dijalankan.

Kata-kata kunci: metode kuantitatif, analisis kuantitatif, teologi praktis, lingkaran empiris.

\section{PENDAHULUAN}

Berbicara tentang penelitian lapangan dalam teologi pada saat ini menurut hemat penulis tidak dapat dipisahkan dengan pemahaman mengenai teologi praktis yang terus berkembang di kalangan dunia akademis. Perkembangan teologi praktis dapat kita lihat melalui orientasi teologi praktis itu sendiri (van der Ven, 1993: 34-41; band. Anderson, 2003: 11 dst.; Ziebertz, 2004). Pada awalnya orientasi teologi praktis adalah pada bagaimana mengaplikasikan disiplin-disiplin teologi yang sudah ada secara efektif dalam tanggung jawab pastoral gereja. Karena itu dalam pengertian ini teologi praktis dapat juga disebut sebagai kumpulan dari metode dan teknik pastoral gereja. Orientasi yang lebih luas dapat kita lihat ketika teologi praktis diarahkan bukan hanya pada pekerjaan pastoral para pejabat gereja saja tetapi pada kehidupan gereja itu sendiri. Di sini subjek dari teologi praktis bukan pejabat gereja melainkan gereja itu sendiri. Di dalam perkembangan lebih lanjut teologi praktis melihat bahwa orientasinya dapat melampaui gereja dan menyentuh persoalan kekristenan serta masyarakat secara umum. Dengan kata lain orientasi ketiga dari teologi praktis adalah pada praksis umat manusia. Umat manusia termasuk gereja di dalamnya adalah subjek yang hidup dengan norma dan nilainilai yang mereka pahami. Semua itu berinteraksi dengan realitas dan perubahan dalam masyarakat, 
seperti kondisi ekonomi, politik dan sosial, konflik, pluralitas, modernitas, dan sebagainya. Proses pemahaman dan interaksi inilah yang kemudian memunculkan praksis di mana proses pertukaran ide dan interpretasi dalam satu komunitas umat manusia terjadi serta menghasilkan pengembangan pemahaman (van der Ven, 1993: 41 dst.). Teologi praktis yang berkembang saat ini lebih dipahami berdasarkan orientasi ketiga. Pemahaman ini kembali pada semangat dasar yang dikembangkan oleh Schleiermacher di tahun 1800-an, yaitu teologi praktis yang adalah sebuah reaksi atau dialog antara hal-hal normatif, yang telah diproduksi oleh disiplin-disiplin ilmu teologi yang lain, dengan bagaimana kehidupan gereja serta manusia itu sendiri secara konkret dalam konteks tertentu. Di dalam pengertian ini, maka teologi praktis dapat dipahami sebagai sebuah disiplin ilmu teologi yang secara serius mengembangkan dan membangun teori teologis atas dasar dan di tengah-tengah praksis serta pengalaman konkret tertentu (Hermans, 2004: 22-24; Anderson, 2003; van der Ven, 1993: 34; Ziebertz, 2004: 295). Atau dengan kata lain, teologi praktis adalah berteori atas praksis manusia dan gereja.

Berdasarkan pemahaman di atas maka ada dua hal penting yang harus diperhatikan dalam teologi praktis. Pertama, kita harus memahami praksis suatu masyarakat atau komunitas yang ada. Proses memahami dan menjelaskan (proses hermeneutis) atas praksis umat manusia menjadi salah satu tugas teologi praktis. Osmer (2008) menyebutnya sebagai tugas deskriptif-empiris. Kita menyadari bahwa metode atau pendekatan teologi yang klasik, seperti: metode teks, historis, dan sistematis, tidak lagi mencukupi. Dibutuhkan pendekatan dan metode yang dapat membantu kita untuk memahami dan menjelaskan praksis. Di sini pendekatan empiris, baik kualitatif maupun kuantitatif, yang biasa dilakukan oleh ilmu-ilmu sosial menjadi relevan bagi teologi praktis (van der Ven, 1993: 77; Osmer, 2008: 49-50). Pendekatan empiris diharapkan menolong kita untuk mendapatkan informasi untuk memahami perubahan, proses interpretasi dan komunikasi atas nilainilai dan konteks dalam kehidupan suatu masyarakat. Kedua, setelah kita mendapatkan hasil dari penelitian empiris atas praksis suatu komunitas maka kita harus membuat evaluasi normatif teologis atas praksis yang kita temukan tersebut, atau yang disebut oleh van der Ven (2002: 16) sebagai “ $a$ normative implication of empirical research in theology". Hal yang terakhir ini yang membedakan penelitian empiris teologis dengan ilmu sosial secara umum. Setiap penemuan penelitian empiris, sekalipun menggunakan pendekatan ilmu sosial, harus dimulai dan dipertemukan kembali dengan persoalan-persoalan teologis. Tentu hasil dari proses evaluasi normatif teologis ini dapat menghasilkan konfirmasi maupun kritik bagi pemikiran-pemikiran teologis, sekaligus memperlihatkan bahwa teologi praktis dengan pendekatan empiris tidak berarti meninggalkan persoalan-persoalan normatif (band. Osmer, 2008: 129 dst.). 
Hal mendasar yang dapat kita lihat dalam pengertian teologi praktis seperti di atas adalah sikap anti-positivis, di mana teori atau norma, termasuk teori atau nilai teologis tertentu, tidak dijadikan sebagai satu-satunya kebenaran yang mati. Tetapi pada saat yang bersamaan tidak berarti suatu praksis terlepas begitu saja dari nilai dan norma tertentu. Nilai dan norma dalam praksis dapat dideteksi melalui perspektif teoretis yang digunakan dalam penelitian empiris (van der Ven, 2002). Singgih (2005: 157) yang sudah cukup lama mendukung pendekatan empiris-induktif dalam penelitian-penelitian teologi melalui lingkaran pastoral mengatakan bahwa pendekatan empiris dapat membangun jembatan antara hal-hal yang bersifat teoretis-normatif dengan berbagai kenyataan konkret yang kontekstual yang ditemukan dalam masyarakat atau komunitas tertentu. Hasil yang diharapkan adalah keterbukaan dan keseimbangan antara yang teoretis dan yang praktis (dan bukan berat sebelah entah kepada yang satu atau yang lainnya) berdasarkan temuan-temuan yang konkret serta dapat dipertanggungjawabkan. Berdasarkan kesadaran mengenai teologi praktis seperti ini maka pembicaraan mengenai metode penelitian empiris menjadi hal yang amat relevan dalam teologi praktis.

Dalam karangan ini penulis secara khusus hendak mengajak kita mendiskusikan peran metode kuantitatif dalam penelitian teologi praktis. Mengapa kuantitatif? Secara umum pendekatan kuantitatif lebih jarang ditemui pada penelitian-penelitian teologis. Menurut hemat penulis hal yang harus dihindari dalam pemilihan sebuah metode penelitian adalah sekadar pada persoalan apa yang disukai dan sudah menjadi tradisi, dan bukan dari fungsi serta tujuan yang mendasar. Penulis ingin mengajak kita untuk memeriksa asumsi-asumsi yang selama ini ada karena janganjangan belum berangkat dari pemahaman yang cukup tentang metode kuantitatif itu sendiri. Setiap metode penelitian, baik kualitatif maupun kuantitatif, memiliki fungsi, tujuan, dan ciri khasnya masing-masing. Fungsi dan tujuan dari masing-masing metode inilah yang harus dipertemukan dengan fungsi dan tujuan suatu penelitian teologis dengan mempertimbangan ciri khas yang ada dari setiap metode penelitian.

Dalam karangan ini penulis mengajukan pertanyaan dasar, sampai sejauh mana metode kuantitatif dapat kita pahami dan lihat relevansinya bagi sebuah metode penelitian empiris-teologis atas praksis gereja? Untuk menjawab pertanyaan ini, penulis menguraikan karangan ini dalam tiga bagian. Pada bagian pertama penulis akan memperlihatkan lingkaran empiris sebagai paradigma metodologis-teologis dalam penelitian teologi praktis di mana metode kuantitatif dilihat sebagai alat yang membantu proses interpretasi atas praksis yang hendak dipahami. Melalui lingkaran empiris ini penulis hendak menempatkan metode kuantitatif dalam perspektif permasalahan teologis. Bagian kedua, penulis akan fokus pada salah satu proses penting dalam lingkaran empiris 
dan pelaksanaan metode kuantitatif, yaitu operasionalisasi serta model-model analisis statistik yang biasa digunakan di lingkungan ilmu sosial. Melalui uraian proses operasionalisasi ini, kita akan bersama-sama melihat bahwa metode kuantitatif memiliki ciri khas, kedalaman, dan tujuannya sendiri dalam mendekati suatu permasalahan teologis. Bagian ketiga, penulis secara singkat memperlihatkan beberapa catatan kritis atas metode kuantitatif bagi penelitian teologi praktis.

\section{LINGKARAN EMPIRIS, TEOLOGI PRAKTIS, DAN METODE KUANTITATIF}

Prosedur dan pendekatan dalam melakukan penelitian empiris untuk teologi praktis diperkenalkan oleh van der Ven (1993: 119 dst.; 2002: 15; band. Hermans, 2004: 23) sebagai the empirical cycle (lingkaran empiris). Lingkaran empiris ini pada dasarnya memberikan tempat pada kedua metode empiris, kualitatif maupun kuantitatif. Tetapi tidak dapat disangkal bahwa cara berpikir lingkaran empiris yang menekankan pentingnya teori yang dioperasionalisasi untuk memahami praksis memberikan ruang yang ramah bagi pendekatan kuantitatif, yang pada dasarnya memahami teori sebagai pintu masuk utama dalam pembacaan suatu masalah empiris (band. David, 2005: 59 dst.). Di bawah ini penulis ingin mengajak kita melihat dan berdiskusi tentang bagaimana relevansi pendekatan lingkaran empiris menurut van der Ven (1993) dan secara khusus pada metode kuantitatif dalam teologi praktis. ${ }^{2}$

Lingkaran empiris dalam teologi praktis dapat digambarkan dalam tahapan-tahapan sebagai berikut: perumusan masalah dan tujuan teologis, induksi, deduksi, analisis/pengujian, dan evaluasi (van der Ven, 1993: 114, 119-156). ${ }^{3}$ Tahap pertama (perumusan masalah dan tujuan teologis) adalah melihat dan menemukan persoalan teologis yang relevan di lapangan. Hal ini mengandaikan bahwa seorang peneliti teologi praktis melakukan refleksi dan mengangkat fenomena yang ada di tengah praksis masyarakat berdasarkan pengamatan dan observasi awal dari kacamata teologis, kemudian menemukan "persoalan-persoalan" serta tujuan penelitian teologis yang hendak dikembangkan. Inti dari persoalan teologis dan tujuan penelitian teologis praktis secara umum adalah soal yang terkait dengan iman kepada Tuhan. Tetapi lebih khusus dalam tahap pertama ini, peneliti dalam teologi praktis berangkat dari praksis umat manusia untuk membangun tujuan penelitian tentang persoalan iman kepada Tuhan.

Pada tahap pertama lingkaran empiris secara khusus penulis hendak menekankan pentingnya keberadaan refleksi dan permasalahan teologis, yang menjamin bahwa pendekatan empiris tidak seharusnya menjadikan teologi praktis terjebak dalam tradisi sosiologis atau ilmu sosial umum 
semata. Hal ini mengingatkan kita pada lingkaran pastoral (pastoral circle) yang sudah lebih dulu kita kenal (band. Henriot, 2005), di mana jiwanya adalah pendekatan dari bawah atau berteologi dengan pendekatan induktif. Pergumulan dan pengalaman praktis tidak lagi diabaikan dalam proses berteologi. Hanya saja pendekatan dan proses observasi bukan lagi dilakukan secara abstrak, melainkan mencoba melihat dan mendalami pengalaman-pengalaman praktis dengan kesadaran paradigma empiris. Pra-penelitian atau pendalaman data empiris yang ada menjadi suatu keharusan. Sebagai contoh, penulis mengangkat persoalan pluralitas agama-agama di Indonesia sebagai salah satu konteks penting kehidupan gereja di Indonesia. Kita tidak dapat menutup mata bahwa ada keragaman sikap pada persoalan ini di tingkat akar rumput tanpa memandang denominasi atau tradisitradisi gereja pada umumnya. Pertanyaan reflektif yang dapat muncul di sini adalah, bagaimana sebenarnya konsep tentang klaim kebenaran dihidupi oleh masyarakat gereja?

Tahap kedua (disebut oleh van der Ven sebagai tahap induksi teologis), adalah upaya lebih jauh untuk memahami persoalan-persoalan dalam praksis suatu komunitas melalui kerangka teori yang relevan. Tahap ini adalah upaya teologi praktis untuk memahami lebih jauh apa yang menjadi substansi persoalan teologis dalam pertanyaan-pertanyaan tahap pertama. Persoalan teologis yang ada dibaca melalui teori-teori teologis maupun teori-teori dalam ilmu sosial. Dalam tahapan inilah persoalan teologis yang umum dikembangkan menjadi formulasi pertanyaan penelitian empiris dan desain penelitian yang lebih konkret.

Sebenarnya penggunaan kerangka teori dalam rangka membaca suatu "permasalahan" bukanlah hal asing dalam dunia akademis. Tetapi ketika hal ini dikerangkakan dalam suatu pendekatan atau prosedur yang cukup ketat dalam penelitian empiris mengingatkan kita pada apa yang disebut sebagai pendekatan deduktif, yang secara umum dipahami sebagai ciri dari metode kuantitatif. Tetapi lalu pertanyaannya, mengapa van der Ven justru menyebutnya sebagai tahap induksi teologis dan bukan deduksi? Menurut penulis hal ini menjadi penting dalam konteks penelitian empiris di bidang sosial seperti teologi praktis. Menurut van der Ven pada dasarnya sulit bagi kita untuk memisahkan secara ketat pendekatan induksi dengan pendekatan deduksi. Hal ini disebut sebagai sebuah false dilema (band. van der Ven, 1993: 115 dst.). Deduksi murni barangkali hanya dapat terjadi ketika kita sedang melakukan penelitian sebagai theory testing atau falsifikasi teori yang mana kuat terjadi dalam dunia eksakta. Tetapi jika kita kembali pada tahapan lingkaran empiris, maka tahap kedua ini adalah sebuah kelanjutan dari tahap pertama, di mana kita sedang menggumuli suatu keadaan atau permasalahan di tengah pengalaman khusus dalam suatu masyarakat/gereja (induktif). Tahap kedua ini adalah kelanjutan untuk mendalami pengalaman masyarakat tersebut melalui sebuah kerangka teori atau kerangka berpikir. Dasar 
berpikir utama dari lingkaran empiris ini adalah relasi dialektis yang kuat antara teori dan praktik/ pengalaman. Van der Ven (2002) dipengaruhi oleh pemikiran epistemologis Karl Popper. Popper berpendapat seperti dikutip oleh van der Ven (2002: 8), “... the methods that we use to observe reality, the very 'facts' that we observe, are all theory-laden. There are no theory-free 'facts' only theory-laden data." Setiap pengalaman dan praksis suatu komunitas disadari atau tidak berlandaskan pada suatu konsep berpikir tertentu (a kind of mental frame of reference) yang kemudian membantu mereka untuk bersikap atas isu-isu terkait. Konsekuensinya ketika seorang peneliti hendak memahami suatu komunitas secara empiris maka ia perlu mendekatinya dengan teori tertentu sebagai kerangka berpikir. Sampai di sini subjek utama dalam penelitian ini tetaplah manusia dengan kekayaan pengalaman dan permasalahannya. Peneliti tetap mengawali proses dalam lingkaran empiris ini dengan pengalaman dan permasalahan manusia (induktif). Teori di sini berperan sebagai alat untuk membantu peneliti mendekati serta mengenali konstruksi berpikir manusia. Sampai di sini kita dapat memahami bahwa tahap kedua justru hendak menegaskan permasalahan induktif yang hendak diangkat. Sebagai contoh: klasifikasi dalam teologi agamaagama yang diperkenalkan, misalnya oleh Knitter (2004), dapat menjadi dasar teori teologis yang relevan untuk membaca praksis yang terjadi dalam masyarakat religius dengan konteks pluralitas agama. Pertanyaan penelitian praktis yang dapat diajukan, sampai sejauh mana masyarakat gereja mengenali model-model klaim kebenaran seperti yang dipahami oleh Knitter? Hal apa yang memengaruhi pembentukan klaim kebenaran tersebut? Di sini permasalahan tentang pluralitas agama-agama dalam masyarakat dilihat melalui persepsi teologis tentang klaim kebenaran yang dihidupi dalam kehidupan religius suatu masyarakat.

Dalam tahap kedua ini pendekatan lintas ilmu, di mana sebuah persoalan teologis dibaca secara empiris melalui kacamata ilmu-ilmu sosial lainnya, menjadi sesuatu yang amat masuk akal. Van der Ven menggambarkan proses ini sebagai berikut (2002: 13): “... the social sciences, and also practical theology, represent a double hermeneutics: it is not only a matter of hermeneutic understanding of traditional and contemporary ideal types and theories, but also and primarily of hermeneutically understanding the meanings concealed in the 'data' in the form of life of groups and communities, to which the researcher, as a citizen and a human being, also belongs." Sebagai contoh, teori tentang identitas sosial, persoalan in-group vs out-group (Tajfel, 1981) digunakan untuk membaca sampai sejauh mana suatu masyarakat religius membangun komunitas sosialnya dalam konteks yang majemuk. Bagaimana mereka merumuskan konsep ingroup dalam interaksi mereka, dan apakah hal tersebut mendorong atau menghalangi interaksi mereka dengan kelompok yang berbeda? 
Tahap ketiga (disebut oleh van der Ven sebagai tahap deduksi teologis), adalah proses lebih lanjut untuk merumuskan pertanyaan penelitian, penyusunan model konsep penelitian, dan operasionalisasi teori yang didapat dari tahap kedua. Dalam proses penyusunan kuesioner untuk survei dalam metode kuantitatif, setiap pertanyaan atau pernyataan yang dibuat harus merujuk pada variabel dan indikator yang jelas dan didasari pada teori tertentu yang telah digunakan pada tahap kedua. Tindakan ini biasa disebut sebagai operasionalisasi teori. ${ }^{4}$ Dengan kata lain, alat penelitian yang berupa pertanyaan atau pernyataan dalam kuesioner adalah turunan langsung dari teori yang menjadi variabel dengan indikator pada setiap variabelnya. Di sini kita dapat memahami bahwa tahapan ini disebut sebagai tahapan deduktif, karena teori diturunkan menjadi alat yang khusus untuk membaca permasalahan. Hal yang penting untuk kita pahami di sini adalah kedua pendekatan, induktif dan deduktif, tidak dipertentangkan di sini (band. van der Ven, 1993:115-118; Ziebertz, 2004). Pertama, pendekatan induktif, di mana fokus awal penelitian adalah pada suatu kondisi yang khusus, dalam praksis suatu masyarakat atau komunitas. Karena itu dalam penelitian empiris, pendekatan induktif mengandaikan suatu tes untuk memeriksa apa dan bagaimana suatu kehidupan dijalankan oleh suatu komunitas. Kedua, pendekatan yang bersifat deduktif. Ketika kita mencoba untuk memahami praksis melalui tes dan metode, kita memerlukan alat, yaitu kerangka teori tertentu, dugaan-dugaan dan hipotesis atas pengalaman praktis suatu komunitas yang akan diformulasikan (operasionalisasi) dalam alat penelitian. Dalam pengertian ini van der Ven menegaskan bahwa pendekatan yang bersifat induktif juga dapat dibantu dengan pendekatan deduktif. Demikian pula pendekatan deduktif tidak begitu saja mengabaikan apa yang bersifat induktif. Pendekatan yang bersifat deduktif dalam tahap ketiga adalah bagian dari pergumulan induktif dalam tahap pertama dan kedua (van der Ven, 2002:13-16; band. Singgih, 2009: 48 dst.). ${ }^{5}$

Tahap keempat, biasa disebut sebagai empirical testing, di mana hipotesis dan pertanyaan penelitian akan diperiksa, seluruh data dikumpulkan, dianalisis, dan diinterpretasi sesuai dengan pertanyaan penelitian. Di sini dibutuhkan metode analisis statistik yang spesifik untuk membaca data. Beberapa macam bentuk analisis statistik yang biasa digunakan oleh ilmu-ilmu sosial, misalnya analisis faktor, untuk pengenalan responden pada konsep yang dibuat oleh peneliti; analisis deskripsi atau frekuensi, untuk membaca kecenderungan atau persetujuan pada sebuah ide; analisis komparasi mean antar-variabel untuk melihat signifikansi perbedaan sikap pada sebuah variabel yang sama; analisis korelasi, untuk melihat keterhubungan antar-variabel; dan analisis regresi, di mana peneliti dapat melihat prediksi pengaruh variabel-variabel tertentu pada variabel dependen yang telah ditentukan (Te Grotenhuis dan van der Weegen, 2009).

Tahap kelima, adalah tahapan normatif di mana data hasil penelitian kembali dievaluasi atau direfleksikan secara teologis. Tahap kelima mengkonfirmasi pendapat yang sudah dibicarakan 
sebelumnya bahwa dalam teologi praktis sebuah penelitian empiris, sekalipun menggunakan pendekatan, teori, dan analisis empiris seperti dalam ilmu sosial, tetap akan dikembalikan pada proses dialektis dengan konsep normatif-teologis yang sudah menjadi fokus sejak awal. Dalam tahap ini proses berteologi praktis sebenarnya tiba pada puncaknya, di mana diskusi dan refleksi teologis berangkat dari pengalaman praktis religius (tindakan, tradisi, budaya, keyakinan) yang sudah didalami dan diinterpretasi dengan baik (band. Killen dan de Beer, 2000: 52 dst.).

Pada akhirnya dalam tahap keenam, teologi praktis bermuara pada apa yang disebut sebagai tugas pragmatis dalam teologi praktis (Osmer, 2008: 176). Di sini teologi praktis akan menawarkan strategi dan pemikiran-pemikiran praktis demi membangun kehidupan dan kepemimpinan komunitas religius di tengah masyarakat.

Sampai di sini kita dapat melihat bahwa lingkaran empiris memperlihatkan bahwa metode kuantitatif dapat bekerja dalam suatu permasalahan teologis. Di sini asumsi bahwa metode kuantitatif bersifat amat positivis dengan pendekatan yang bersifat deduktif pada dasarnya dikritisi. Tetapi saat ini kita juga perlu melihat lebih dalam bagaimana metode kuantitatif ini bekerja dalam lingkaran empiris, khususnya pada tahap operasionalisasi dan analisis, untuk dapat memahami apa yang menjadi kekuatan maupun kelemahan metode ini dalam suatu penelitian teologis.

\section{PROSES OPERASIONALISASI DALAM METODE KUANTITATIF}

Di atas telah dijelaskan bahwa dalam proses operasionalisasi seorang peneliti akan menerjemahkan teori yang telah dirumuskan dalam model konsep penelitian ke dalam alat ukur yang diharapkan dapat mengungkapkan realitas dan praksis suatu komunitas. Karena itu proses operasionalisasi ini harus dilakukan setepat mungkin. Alat ukur atau kuesioner tersebut harus mendalam, valid, dan dapat diandalkan berdasarkan teori-teori yang digunakan, tetapi sekaligus juga mampu dipahami dengan baik oleh para responden yang akan menjawabnya. Sampai di sini pertanyaan yang sering kali muncul adalah sampai sejauh mana pertanyaan-pertanyaan survei dalam kuesioner dapat menjadi alat ukur yang memadai untuk persoalan-persoalan teologis? Bagaimana pendekatan kuantitatif dengan sistem numerik dapat menjadi alat untuk pengukuran konsep teologis? Bagaimana proses operasionalisasi konsep dapat merepresentasikan makna yang otentik dan keunikan dari tindakan dan perkataan orang-orang dalam suatu komunitas (band. van der Ven, 2002: 16)? Jawaban serta diskusi atas pertanyaan-pertanyaan ini penulis akan perlihatkan melalui beberapa tahapan penting dalam proses operasionalisasi teori. 


\section{Relasi Teori dan Sistem Empiris}

Proses operasionalisasi teori mengaitkan tiga unsur utama yang penting, yaitu: teori/konsep, sistem empiris, dan sistem numerik (band. Huber, 2009). Teori atau konsep harus dikomunikasikan ke dalam sistem empiris di mana pengetahuan, pemahaman perkataan, dan tindakan suatu komunitas religius terintegrasi dalam praktik. Artinya di sini, proses operasionalisasi bukanlah sekadar menempelkan teori pada praktik. Teori digunakan dan dioperasionalisasi dengan mempertimbangkan apa yang benar-benar terjadi dalam tindakan praktis. Pada saat yang bersamaan sistem numerik yang digunakan oleh metode kuantitatif dalam teologi praktis juga harus terkait dengan sistem empiris. Pada paragraf selanjutnya persoalan sistem numerik ini akan dibahas lebih jauh. Huber ${ }^{6}$ menggambarkan relasi ketiga unsur yang disebutkan di atas sebagai berikut.

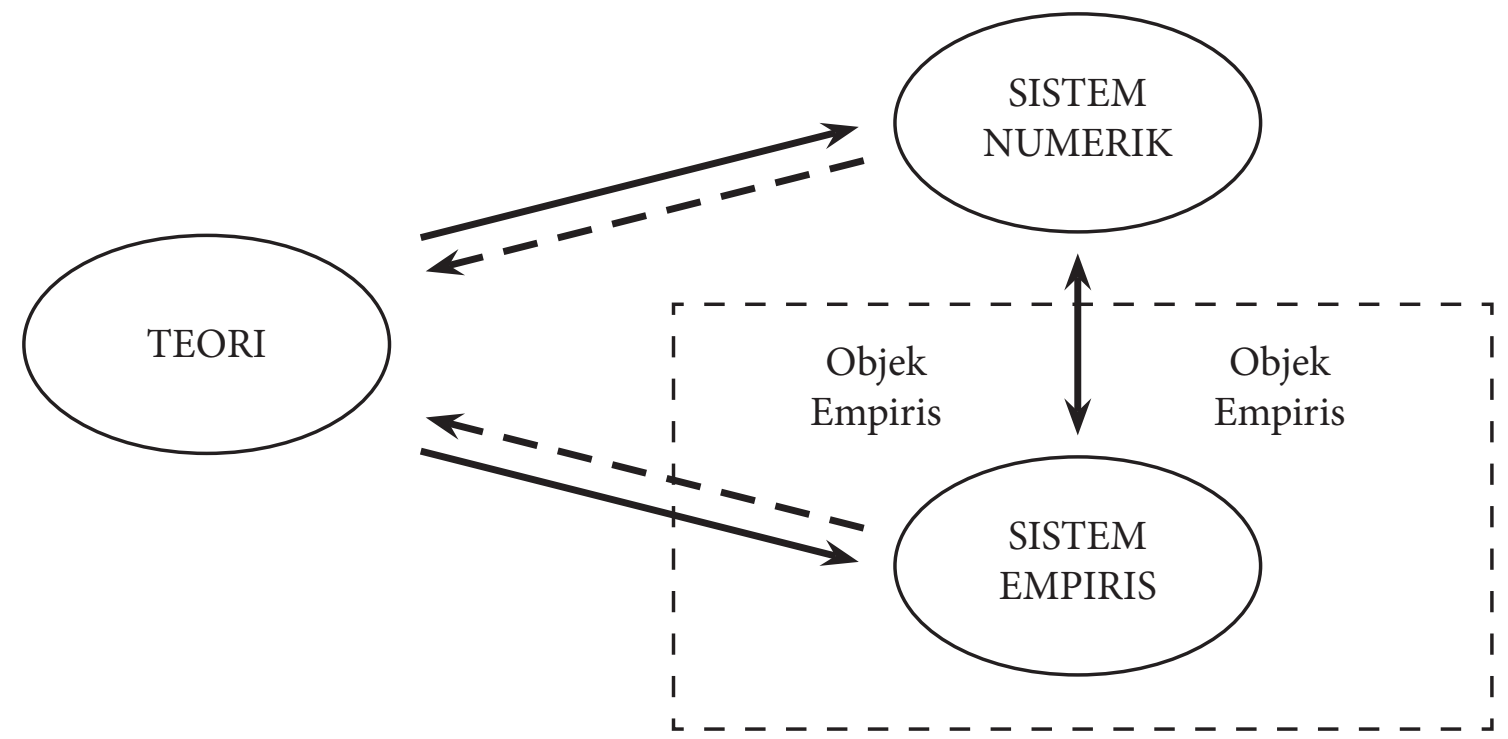

Uraian Hermans (2004) ketika menjelaskan teologi dan penelitian empiris dapat membantu kita untuk melihat lebih jauh relasi antara teori dan sistem empiris dalam penelitian teologi praktis. Menurut Hermans (2004: 47): "Practical theological theory should focus on the common sense understanding of religion as practised by people and formulate religious ideas that incorporate indeterminateness." Ide-ide religius yang dimaksud di sini menurut Hermans menyangkut dua hal, yaitu apa yang dipahami dan apa yang dilakukan dalam tindakan. Hal-hal yang dipahami oleh komunitas agama terkait dengan ide-ide religius oleh Hermans, mengikuti Charles Sanders Peirce (2004: 35-45), disebut sebagai ide yang samar (the vague ideas). Apa yang dimaksud dengan ide yang samar bukan tentang hal yang irasional, tetapi apa yang berada di antara yang pasti dan tidak pasti, hal yang sudah terjadi tetapi juga mungkin akan terjadi. Dalam konteks teologi praktis, ide religius yang samar ini, misalnya, "keberadaan Tuhan" atau konsep bahwa "Tuhan akan menolong mereka yang menderita”. Pengertian tentang keberadaan Tuhan ini kemudian menuntun dan membentuk 
tindakan-tindakan atau sikap religius. Memahami tindakan atau sikap religius pada dasarnya adalah upaya memahami ide yang samar, dan dalam persepektif teologi praktis tindakan atau sikap religius itu dapat ditemukan di dalam tindakan manusia itu sendiri, atau dalam istilah yang digunakan Huber adalah sistem empiris. Hermans (2004: 43) menggambarkan hal ini sebagai: "the concrete religious life of the believer is an interpretation of the meaning of vague religious ideas".

Berdasarkan hal di atas tindakan operasionalisasi teori harus ditempatkan pertama-tama dalam perspektif untuk menghasilkan alat guna memeriksa tindakan-tindakan atau sikap manusia yang adalah cerminan ide-ide religius yang samar (band. Hermans, 2004: 41-45). Penelitian tentang sikap sudah lama dilakukan oleh penelitian kuantitatif sosiologis dan psikologi sosial. Pada intinya penelitian semacam ini mengukur persetujuan responden pada suatu pernyataan sikap (religius) tertentu yang dituliskan dalam kuesioner. Kuesioner adalah hasil akhir dari tahap operasionalisasi teori yang adalah perspektif normatif-teologis dan diterjemahkan dalam bentuk sikap religius tertentu yang operasional dalam praksis komunitas religius. Kuesioner menjadi alat yang amat menentukan seberapa jauh data dari responden dapat digali. Tentu sebuah kuesioner yang adalah hasil dari operasionalisasi teori tidak akan pernah dapat menjelaskan semua proses berteologi dan sikap religius yang dinamis dan luas. Karena itu kita menyadari bahwa semakin dalam dan luas konsep teori digunakan oleh seorang peneliti maka akan semakin luas tindakan atau sikap religius yang dapat kita gali melalui kuesioner. Di bawah kita akan melihat bagaimana proses operasionalisasi ini dilaksanakan secara praktis.

\section{Variabel Pengukuran, Indikator, dan Alat Penelitian}

Operasionalisasi teori dalam penyusunan kuesioner dalam metode kuantitatif secara praktis terdiri dari tahap perumusan variabel pengukuran, perumusan indikator, dan penulisan alat penelitian dalam kuesioner (band. David, 2005: 135 dst..; Pennings, Keman, dan Kleinnijenhuis, 2006: 56 dst.). Untuk dapat memahami lebih jauh penulis akan mencoba membahas setiap tahap dengan contoh.

Proses perumusan variabel pengukuran, yaitu upaya kita untuk menjabarkan suatu teori ke dalam beberapa model atau kelompok pengukuran. Variabel-variabel pengukuran yang dibentuk di sini berangkat dari pemahaman konsep teoretis yang kita gunakan, dan kita akan uji di dalam sistem empiris yang ada. Sebagai contoh, ketika kita hendak meneliti penghayatan relasi agamaagama yang berbeda di tengah suatu komunitas, maka teologi agama-agama dapat kita pilih sebagai teori yang relevan yang dapat kita gunakan untuk memeriksa sampai seberapa jauh sikap religius pada klaim kebenaran dijalankan di tengah konteks agama-agama yang berbeda. Di sini kemudian teologi agama-agama seperti yang diuraikan oleh Knitter (2004) dijabarkan ke dalam 
beberapa variabel pengukuran, misalnya: model penggantian, model pemenuhan, model kesamaan, dan model penerimaan. Contoh lain, misalnya persoalan sosio-teologis hubungan negara-agama. Konsep dan teori yang terkait dengan relasi negara-agama, misalnya, adalah liberalisme dan komunitarianisme (Rawls, 2001; Taylor, 1994). Dari kedua teori ini kita mendapatkan dua variabel yang mencerminkan sikap sosio-religius yang berbeda. Variabel pertama, mereka yang memandang kebebasan individu sebagai hal yang amat penting. Variabel kedua, mereka yang memahami bahwa selalu ada nilai-nilai bersama yang mengikat setiap orang dalam komunitas besar.

Proses berikutnya adalah menjabarkan setiap variabel ke dalam indikator-indikator pengukuran yang akan digunakan untuk merumuskan kuesioner/alat penelitian. Indikator yang diambil dari teori yang digunakan bukanlah sekadar definisi tetapi uraian yang memperlihatkan bagaimana suatu variabel pengukuran dapat kita pahami dan titik tolak bagaimana kuesioner sebagai alat ukur kelak dibuat. Sebagai contoh, variabel model penggantian dalam teologi agamaagama dapat diuraikan ke dalam indikator, yaitu: sebuah sikap yang melihat kebenaran iman yang valid itu hanya melalui satu agama yaitu agamanya sendiri. Dalam variabel model penggantian ini kebenaran bersifat tunggal dan universal. Kata-kata kunci yang dapat kita temukan dalam indikator ini adalah: kebenaran tunggal, kebenaran universal, pemilik kebenaran yang valid.

Contoh lain, misalnya dalam variabel liberalisme radikal, indikator sesuai teori dapat kita tuliskan adalah: agama tidak diperkenankan sama sekali melakukan intervensi apa pun kepada negara. Dalam konsep ini agama dipahami sebagai sebuah entitas yang bekerja di dalam ranah privat dan bersifat individual, sedangkan negara ada dalam ranah publik di mana negara harus menghargai kebebasan individu secara total. Berdasarkan hal ini relasi negara dan agama dalam liberalisme radikal adalah terpisah secara total.

Proses yang terakhir adalah rumusan alat ukur dalam kuesioner. Di sini indikator-indikator yang ada dari setiap variabel dijadikan dasar penyusunan alat ukur. Tahap merumuskan kuesioner ini perlu mempertimbangkan beberapa hal penting, yaitu: pertama-tama adalah pengenalan kita pada sistem semantik yang hidup dalam realitas masyarakat. Ketika suatu konsep atau teori benarbenar dijabarkan menjadi sebuah atau beberapa buah pertanyaan/pernyataan alat pengukuran maka semua itu tentu harus memiliki relevansi yang kuat dengan realita yang ada. Terkait dengan hal ini Huber (2009) mengingatkan bahwa kalimat dan kata yang digunakan dalam item alat ukur harus diperhatikan dengan baik dalam kaitannya dengan sistem empiris, sekalipun kita berangkat dari indikator teoretis. Kita harus memastikan apakah istilah, kata, atau konsep yang kita gunakan dapat dikenali oleh responden yang mewakili populasi atau komunitas yang kita periksa.

Dua tabel di bawah ini adalah contoh operasionalisasi dari konsep tentang teologi agamaagama dan relasi negara-agama (band. Hadiwitanto, 2016: 111, 133). 
Tabel 1: Operasionalisasi Teori Teologi Agama-Agama

\begin{tabular}{|l|l|}
\hline \multicolumn{1}{|c|}{ Perspektif Teoretis } & \multicolumn{1}{c|}{ Pernyataan Alat Ukur } \\
\hline \multirow{5}{*}{ Model Penggantian } & Agama-agama lain tidak menawarkan pengalaman sejati tentang Tuhan. \\
\cline { 2 - 3 } Model Pemenuhan & $\begin{array}{l}\text { Kebenaran tentang Tuhan, manusia, dan alam semesta hanya ditemukan dalam agama } \\
\text { penulis. }\end{array}$ \\
\hline \multirow{5}{*}{ Model Kesamaan } & $\begin{array}{l}\text { Dibandingkan dengan agama penulis, agama-agama lain hanya mengandung sebagian } \\
\text { kebenaran saja. }\end{array}$ \\
\cline { 2 - 3 } & $\begin{array}{l}\text { Agama-agama yang lain pada akhirnya akan menemukan kesempurnaannya dalam } \\
\text { agama penulis. }\end{array}$ \\
\hline \multirow{3}{*}{ Model Penerimaan } & $\begin{array}{l}\text { Agama yang berbeda mengungkap aspek yang berbeda dari kebenaran hakiki yang } \\
\text { sama. }\end{array}$ \\
\cline { 2 - 2 } & $\begin{array}{l}\text { Persamaan-persamaan antar-agama adalah dasar untuk membangun suatu agama } \\
\text { universal. }\end{array}$ \\
\cline { 2 - 2 } & Semua agama menyediakan pengalaman yang mendalam tentang Tuhan. \\
\hline
\end{tabular}

Tabel 2: Operasionalisasi Teori Relasi Negara-Agama

\begin{tabular}{|c|c|c|}
\hline Perspektif Teoretis & Model Teoretis & Pernyataan Alat Ukur \\
\hline \multirow{4}{*}{ Liberalisme } & \multirow[t]{2}{*}{ Liberalisme Radikal } & $\begin{array}{l}\text { Negara dan tradisi religius seharusnya saling berdiri sendiri dan } \\
\text { tidak saling mencampuri. }\end{array}$ \\
\hline & & Negara dan agama seharusnya dipisahkan secara total. \\
\hline & \multirow{2}{*}{ Liberalisme Moderat } & $\begin{array}{l}\text { Negara seharusnya melindungi semua agama dalam masyarakat } \\
\text { tanpa membeda-bedakan. }\end{array}$ \\
\hline & & $\begin{array}{l}\text { Negara seharusnya melindungi semua komunitas agama demi } \\
\text { terciptanya keanekaragaman. }\end{array}$ \\
\hline \multirow{4}{*}{ Komunitarianisme } & \multirow{2}{*}{$\begin{array}{l}\text { Komunitarianisme } \\
\text { Moderat }\end{array}$} & $\begin{array}{l}\text { Negara seharusnya mendukung komunitas agama yang berbeda- } \\
\text { beda dan meneruskan nilai-nilai mereka. }\end{array}$ \\
\hline & & $\begin{array}{l}\text { Negara seharusnya mempromosikan tradisi-tradisi keagamaan } \\
\text { dan menggunakan nilai-nilai mereka. }\end{array}$ \\
\hline & \multirow[t]{2}{*}{$\begin{array}{l}\text { Komunitarianisme } \\
\text { Radikal }\end{array}$} & $\begin{array}{l}\text { Negara seharusnya menjadikan nilai-nilai agama penulis } \\
\text { sebagai dasar seluruh kehidupan masyarakat. }\end{array}$ \\
\hline & & $\begin{array}{l}\text { Negara seharusnya didasarkan pada nilai dan norma-norma } \\
\text { agama penulis. }\end{array}$ \\
\hline
\end{tabular}

Dalam Tabel 1 dan 2 kita melihat contoh bagaimana konsep/teori yang diturunkan menjadi variabel-variabel (dalam perspektif teoretis) dan berdasarkan indikator yang dipahami pada setiap variabel dibuatlah pertanyaan atau pernyataan alat penelitian yang akan dituliskan dalam kuesioner. Respon pada alat ukur seperti contoh di atas biasanya adalah sikap ketidaksetujuan atau persetujuan, yang kemudian dapat dianalisis kecenderungan persetujuannya. 


\section{Pengukuran dengan Sistem Numerik dan Proses Analisis Statistik}

Kritik yang biasa muncul terkait metode kuantitatif dalam penelitian teologi adalah, bahwa persoalan teologis tidak dapat begitu saja dikuantifikasikan dengan angka. Di sini penulis mencoba untuk menjelaskan sistem numerik yang digunakan dalam metode kuantitatif dan memperlihatkan relevansi kritisnya bagi sebuah penelitian teologis.

Pertama, kita perlu memahami bahwa sistem numerik di sini adalah angka-angka yang digunakan untuk kodifikasi dan mengukur jawaban dari pertanyaan atau pernyataan dalam kuesioner. Kedua, sistem numerik dibutuhkan karena pendekatan kuantitatif menggunakan analisis statistik, di mana jawaban atas suatu alat ukur harus menggunakan angka agar dapat dihitung. Perhitungan statistik di sini misalnya, jumlah atau persentase, nilai rata-rata persetujuan atas suatu sikap, nilai signifikansi perbedaan antar-satu sikap dengan sikap yang lain, korelasi antar-variabel, dan sebagainya. Pada dasarnya sistem numerik adalah alat bantu untuk proses analisis statistik. Di balik angka-angka tersebut ada variabel dengan konsep atau teori tertentu yang dioperasionalisasi dalam bentuk pertanyaan atau pernyataan sikap religius yang kemudian diukur dengan angka.

Sistem numerik yang biasa digunakan dalam metode kuantitatif sosial dan relevan dengan penelitian teologis (seperti yang telah dibahas di atas) adalah pengukuran sikap, khususnya sikap religius. Pengukuran sikap biasanya menggunakan Skala Likert, di mana ketidaksetujuan dan persetujuan diukur dengan angka 1-5 (continuum scale). Sebagai contoh: 1 = sangat tidak setuju atau sangat tidak penting; 2 = tidak setuju atau tidak penting; $3=$ tidak tahu atau ragu-ragu; 4 setuju atau penting; 5 = sangat setuju atau sangat penting. Konsep sikap dan sistem numerik akan merepresentasikan realitas, baik pengetahuan yang dimiliki oleh responden (dimensi kognitif) maupun apa yang dipahami secara kritis oleh responden (dimensi afektif-evaluatif). Secara umum dalam penelitian-penelitian teologi praktis operasionalisasi konsep ke dalam alat penelitian yang mengukur sikap religius memiliki relevansi dengan dan memberikan kontribusi penting bagi pengenalan kita pada praksis teologis suatu komunitas.

Di bawah ini kami tunjukkan contoh kuesioner tentang klaim kebenaran (berdasarkan teori teologi agama-agama) dengan skala sikap (Hadiwitanto, 2016: 111):

Pertanyaan-pertanyaan berikut ini menyangkut tentang hubungan dengan agama yang berbeda.

$$
\begin{aligned}
& 1=\text { sama sekali tidak setuju } \\
& 2=\text { tidak setuju } \\
& 3=\text { ragu-ragu } \\
& 4=\text { setuju } \\
& 5=\text { setuju sepenuhnya }
\end{aligned}
$$




\begin{tabular}{|l|l|l|l|l|l|}
\hline & 1 & 2 & 3 & 4 & 5 \\
\hline $\begin{array}{l}\text { 1. } \\
\text { Agama-agama lain tidak menawarkan pengalaman sejati tentang } \\
\text { Tuhan. }\end{array}$ & & & & & \\
\hline 2. & $\begin{array}{l}\text { Agama-agama yang lain pada akhirnya akan menemukan } \\
\text { kesempurnaannya dalam agama penulis. }\end{array}$ & & & & \\
\hline 3. & $\begin{array}{l}\text { Persamaan-persamaan antar-agama adalah dasar untuk } \\
\text { membangun suatu agama universal. }\end{array}$ & & & & \\
\hline 4. Semua agama adalah jalan menuju kebenaran yang hakiki. & & & & & \\
\hline
\end{tabular}

Sistem numerik ini terkait erat dengan metode analisis statistik yang biasa juga digunakan dalam penelitian sosial (band. te Grotenhuis dan van der Weegen, 2009; Field, 2005), di antaranya adalah deskripsi statistik, analisis faktor, analisis korelasi, dan analisis regresi.

Deskripsi statistik adalah analisis dengan perhitungan statistik yang paling sederhana pada data-data sederhana tetapi memberikan informasi penting yang mendasar. Hal yang sangat umum dilakukan dalam deskripsi statistik adalah melihat jumlah atau persentase. Misalnya berapa jumlah atau persentase responden berdasarkan variabel tertentu, seperti: usia, jender, tingkat pendidikan, atau pertanyaan tertentu yang sederhana. Sebagai contoh, jumlah atau persentase responden yang menjawab pertanyaan: "Apakah Anda percaya bahwa Yesus adalah Tuhan yang juga pencipta langit dan bumi?" Di dalam tingkatan yang lebih tinggi seperti kuesioner yang mengukur sikap dengan continuum scale di atas (skala 1-5, bahkan ada yang 1-7), maka deskripsi statistik membutuhkan analisis yang lebih rumit, misalnya yang paling sering digunakan adalah analisis nilai rata-rata atau mean. Nilai mean berarti menunjukkan nilai tengah dari distribusi jawaban yang ada. Nilai tengah ini menggambarkan sampai sejauh mana kelompok responden yang mewakili satu populasi itu memiliki kecenderungan. Sebagai catatan, kita melihat ciri yang paling khas dari metode kuantitatif dengan survei dan analisis statistik ini, yaitu penggambaran secara umum (generalisasi) suatu populasi. Analisis kuantitatif dengan sistem survei mengandaikan bahwa kita memiliki responden yang dipilih secara random dan mewakili populasi besar yang menjadi induknya. Konsekuensinya adalah, nilai penyebaran dari nilai tengah (standard deviation) juga perlu dipertimbangkan sebelum kita mengambil kesimpulan bahwa nilai tengah itu memberikan informasi yang kuat tentang populasi tersebut. Semakin besar nilai penyebarannya (biasanya bila di atas 1 dalam skala Likert 1-5) maka semakin kurang valid nilai tengahnya. Sebaliknya semakin kecil nilai penyebaran, maka nilai tengah yang ada semakin dapat diterima.

Analisis faktor, adalah upaya untuk melihat bagaimana secara statistik setiap item pernyataan/ pertanyaan saling terkait dengan item yang lain membentuk satu atau lebih faktor (pengelompokan). Dalam analisis ini seorang peneliti menguji konstruksi teoretis yang ia sendiri buat dalam proses 
deduksi (operasionalisasi) tetapi pada saat bersamaan menginterpretasi konstruksi yang dipahami oleh responden sebagai subjek penelitian. Hasil dari faktor analisis dapat menolong kita untuk melihat sampai sejauh mana teori berkorelasi dengan responden dalam pengalaman praktisnya. Apalagi menimbang bahwa konsep-konsep teologis tertentu berjumpa dengan logika-logika mengenai ide yang samar dalam agama, kadang kala dapat membuat apa yang dipikirkan secara konseptual belum tentu persis sama dengan apa yang dipahami dan dikenali oleh responden. Hasil dari analisis faktor ini dapat menjadi konfirmasi maupun eksplorasi atas teori yang kita gunakan (band. Field, 2005: 619 dst.). Sebagai contoh, konsep teoretis teologi agama-agama memperlihatkan lima variabel pengukuran dengan item-item yang menjadi alat ukur masing-masing variabel tersebut, yaitu model penggantian, model pemenuhan, model kesamaan, dan model penerimaan. Dalam analisis faktor ini kita dapat menguji apakah alat ukur/kuesioner yang kita buat telah sesuai dengan konsepnya. Tetapi selain itu juga melalui analisis faktor kita dapat menguji bagaimana responden itu sendiri merespon konsep teoretis yang telah kita susun. Interpretasi atas respon ini, termasuk ketika ada perbedaan antara konsep teori yang digunakan, memperlihatkan situasi praktis dan pengalaman responden yang khas. Di sini penelitian kuantitatif kembali memberikan tempat pada pendekatan induktif.

Analisis korelasi, adalah upaya statistik untuk melihat sampai sejauh mana satu variabel berkorelasi secara signifikan dengan variabel yang lain (te Grotenhuis dan van der Weegen, 2009: 45; Field, 2005: 107 dst.). Jika ditemukan korelasi positif antara dua variabel, maka itu berarti jika satu variabel disetujui oleh responden maka responden yang sama juga akan mendukung variabel yang lain. Demikian pula, jika satu variabel tidak disetujui oleh responden maka responden yang sama juga tidak menerima variabel yang lain. Sedangkan korelasi negatif menunjukkan situasi yang berbeda, yaitu ketika responden menerima satu variabel maka responden yang sama menolak variabel yang lain. Analisis korelasi memperlihatkan kepada kita sampai sejauh mana suatu konsep dan sikap teologis tertentu memiliki hubungan dengan konsep atau sikap yang lain. Korelasikorelasi yang ditemukan dapat memperlihatkan kepada kita kedalaman karakteristik pemikiran dan sikap religius suatu kelompok masyarakat.

Analisis regresi, adalah analisis yang dilakukan untuk membuktikan hipotesis tentang variabel independen apa yang memengaruhi variabel dependen (band. te Grotenhuis dan van der Weegen, 2009: 93 dst.; Field, 2005: 143 dst.). Dalam analisis regresi, kita melakukan perhitungan statistik untuk menguji sampai sejauh mana satu atau beberapa variabel tertentu memberikan pengaruh yang signifikan pada satu variabel atau satu sikap religius yang dihipotesiskan sebagai dependent variable. Misalnya, kita hendak membuktikan hipotesis bahwa gambaran Yesus tertentu adalah variabel yang memengaruhi terbangunnya sikap eksklusif dalam teologi agama-agama di tengah masyarakat plural. 


\section{CATATAN KRITIS PADA METODE KUANTITATIF DALAM TEOLOGI PRAKTIS}

Setelah kita melihat secara kritis bagaimana metode kuantitatif dapat bekerja dalam sebuah penelitian teologis, maka di sini penulis hendak memberikan beberapa catatan kritis.

1. Pada dasarnya metode kuantitatif, seperti juga metode kualitatif, adalah alat bantu bagi sebuah penelitian lapangan, termasuk penelitian dalam teologi praktis. Metode kuantitatif memiliki filosofi, prosedur, dan metode analisisnya sendiri untuk menjelaskan secara objektif bagaimana suatu praksis masyarakat berjalan. Karena itu ketika teologi praktis memiliki perhatian khusus untuk memahami praksis masyarakat religius dan gereja (pendekatan induktif), maka kita perlu menyadari bahwa metode kuantitatif adalah satu kemungkinan yang juga dapat kita gunakan di samping metode kualitatif. Kecenderungan untuk menolak metode kuantitatif dan lebih menerima metode kualitatif sekadar didasari oleh tradisi serta kebiasaan yang bersifat emosional bukanlah sikap yang tepat dan akademis. Kecenderungan dalam penelitian-penelitian lapangan pada saat ini di mana kedua metode justru digunakan bersama-sama demi mendapatkan data empiris yang lengkap semakin menegaskan bahwa penelitian lapangan teologis juga tidak semestinya menghindari metode kuantitatif.

2. Metode penelitian kuantitatif tentu memiliki perbedaan mendasar dengan metode kualitatif. Salah satu hal yang sering dibicarakan adalah bahwa metode kuantitatif bersifat deduktifkarena penggunaan teori yang amat ketat dalam penyusunan alat penelitian (kuesioner); sedangkan metode kualitatif dipahami lebih bersifat induktif karena secara serius berupaya memahami dan menemukan apa yang terjadi dalam praksis masyarakat melalui kata-kata, wacana, bahasa, paradigma, gestur, dan sebagainya, di mana alat penelitian ada pada si peneliti sendiri. Pendekatan lingkaran empiris seperti yang sudah penulis jelaskan di atas memperlihatkan bahwa pemahaman tentang persoalan induktif dan deduktif ini sebenarnya dapat kita lihat dengan kritis. Dalam penjelasan tentang lingkaran empiris, kedua istilah ini digunakan bersama-sama. Pada dasarnya lingkaran empiris memperlihatkan bahwa suatu penelitian dengan metode kuantitatif tetap berangkat dari kesadaran induktif tentang permasalahan atau kegelisahan teologis. Di sini pengamatan dan refleksi teologis memiliki tempat yang amat penting sebagai titik awal permasalahan. Pendekatan deduktif barulah terlihat ketika tahap operasionalisasi dimulai, di mana teori yang digunakan diturunkan menjadi variabel, indikator, dan alat penelitian (kuesioner). Tetapi jelas dalam lingkaran empiris ini penelitian teologi praktis dengan metode kuantitatif bukanlah sekadar penelitian deduktif yang theory-oriented dan bertujuan sekadar untuk uji teori, melainkan suatu penelitian yang dimulai dan dengan 
kesadaran induktif serta bertujuan practice-oriented (band. Verschuren dan Doorewaard, 1999: 36 dst.). Kita tidak boleh melupakan peran dari analisis faktor di mana pengenalan responden pada konsep teori yang telah dipilih dan dirumuskan oleh peneliti juga tetap diperiksa. Hasil dari analisis faktor dapat memberikan gambaran pemahaman praktis responden yang tidak selalu sama dengan konsep teori karena mereka memiliki pengalamannya sendiri berdasarkan situasi atau konteks yang ada (Hadiwitanto, 2016: 176 dst.; Field, 2005: 619 dst.). Di sini kembali kita melihat bahwa pendekatan induktif juga memainkan peran yang penting dalam metode kuantitatif. Dengan demikian maka metode kuantitatif seharusnya dapat menjadi alternatif dalam penelitian teologi praktis. Persoalan yang perlu kita perhatikan lebih jauh adalah sampai sejauh mana tujuan dan permasalahan penelitian yang dirumuskan cocok dengan metode kuantitatif. Untuk hal ini kita perlu melihat secara kritis kekuatan maupun kelemahan metode kuantitatif dengan model-model analisisnya.

3. Jika kita melihat dengan baik cara kerja metode kuantitatif seperti yang sudah dijelaskan di atas, terutama pada proses operasionalisasi dan metode-metode analisis yang ada, maka kita mendapatkan beberapa hal penting yang menjadi kekuatan.

- Metode kuantitatif membantu peneliti untuk mengenali suatu masyarakat berdasarkan perspektif teoretis yang jelas dan terbatas. Operasionalisasi teori ke dalam alat penelitian/ kuesioner membatasi penelitian yang sedang dilakukan tanpa kuatir meluas pada hal-hal lain yang bersifat subjektif-spekulatif. Pembatasan permasalahan di sini dapat dilihat sebagai hal yang positif dalam arti bahwa penelitian lapangan yang dilakukan menjadi amat fokus dan berjarak. Tentu hal ini perlu ditunjang oleh proses studi literatur dan perumusan konsep teori yang baik (tahap kedua lingkaran empiris) serta operasionalisasi yang teliti (tahap ketiga lingkaran empiris).

- Proses operasionalisasi dengan sistem numerik yang memeriksa skala sikap serta analisisanalisis yang digunakan dalam metode kuantitatif semestinya mematahkan stereotip bahwa metode kuantitatif bersifat tidak mendalam. Ada dua hal yang perlu diperhatikan di sini. Pertama, sepanjang konsep teori dan variabel-variabel yang digunakan cukup lengkap maka hal tersebut akan membantu penelitian ini juga menjadi semakin dalam. Konsekuensi dari banyaknya variabel penelitian adalah pada alat penelitian/kuesioner yang akan menjadi panjang, tetapi bukan hal yang tidak mungkin dilakukan. Kedua, fokus penelitian adalah pada sikap religius yang adalah wujud konkret yang terukur atas sikap iman dan teologis yang dihidupi oleh suatu masyarakat religius. Analisis deskriptif pada sikap religius memberikan gambaran pada kecenderungan suatu masyarakat yang 
diteliti tentang sikap religius tertentu. Informasi ini masih bisa diperdalam dengan analisis korelasi dan regresi yang dapat menganalisis karakteristik hubungan-hubungan antarvariabel serta prediksi pembentuk atau penantang suatu sikap religius. Karakteristik dan prediksi pada suatu sikap religius tertentu ini memperlihatkan bagaimana suatu sikap religius yang sedang diteliti itu dibangun oleh suatu komunitas.

- Pengumpulan data dengan menggunakan kuesioner sebagai alat penelitian (survei) menuntut metode sampel sebagai cara pengumpulan data. Hal ini memungkinkan metode kuantitatif dilakukan pada subjek penelitian dalam wilayah yang luas. Hal ini akan menguntungkan ketika persoalan penelitian teologi praktis yang ada adalah persoalan-persoalan makro, tanpa meniadakan kemungkinan pembahasan permasalahanpermasalahan teologi praktis yang bersifat mikro maupun meso (band. Hadiwitanto, 2010: 134). Dalam sebuah penelitian yang besar peneliti dapat menjadikan data makro sebagai data awal yang kemudian dilanjutkan dengan penelitian-penelitian kualitatif mendalam pada konteks-konteks yang lebih spesifik. Di sini baik data kuantitatif maupun kualitatif dapat saling melengkapi.

4. Tentu kita juga harus melihat bahwa metode kuantitatif ini memiliki kelemahan yang perlu kita sadari dalam konteks penelitian teologis.

- Penggunaan perspektif teori yang amat kuat dalam proses penyusunan permasalahan sampai dengan alat penelitian, di samping secara positif dapat membantu fokus penelitian, tidak dapat disangkali membatasi pendalaman pada subjek penelitian. Sekalipun dengan analisis faktor peneliti juga akan mempertimbangkan pemahaman dan pengalaman responden atas konsep teori yang digunakan, tetapi kesan bahwa metode kuantitatif ini kurang bersifat induktif tidak dapat disangkal. Penelitian akan sangat terbatas dan fokus pada konsep teori yang digunakan oleh peneliti dan tidak jarang mengabaikan apa yang sebenarnya terjadi dalam praktik lapangan yang ada. Persoalan lain yang dapat dilihat di sini adalah keterbatasan pemilihan teori untuk membaca permasalahan (tahap kedua lingkaran empiris). Pada dasarnya diperlukan keluasan dan kecermatan yang kuat dalam pemilihan konsep teori yang akan dioperasionalisasi menjadi alat penelitian. Ketika hal ini disederhanakan seolah seorang peneliti dapat menggunakan teori apa saja tanpa studi mendalam atas teori-teori tersebut dan relevansinya atas permasalahan penelitian yang ada, maka penelitian kuantiatif justru dapat mengkhianati subjek penelitian dengan pendekatan yang subjektif serta melanggar prinsip hermeneutik dalam suatu penelitian. 
- Kita perlu menyadari bahwa sekalipun pemeriksaan data tentang sikap religius pada dasarnya juga dapat memperlihatkan kedalaman, tetapi metode kuantitatif nyaris tidak memberikan alternatif data lain. Analisis-analisis statistik dapat memberikan kedalaman melalui korelasi antar-variabel (karakteristik) dan prediksi-prediksi dari suatu variabel pada variabel penelitian lainnya. Tetapi data yang didapat terbatas pada teori dan variabel yang telah ditentukan dalam alat penelitian/kuesioner. Peneliti tidak bisa mendapatkan data tambahan dan mengembangkan pertanyaan di luar alat penelitian/kuesioner yang ada. Selain itu juga sistem numerik dalam statistik dalam metode kuantiatif akan kesulitan untuk mengukur pendalaman di luar deskripsi jumlah, persetujuan, dan pengukuran pada sikap. Sebagai contoh, amat sulit metode kuantitatif menemukan data terkait ide dan kedalaman wacana yang hidup dalam suatu komunitas. Atau metode ini juga tidak dapat dengan mudah menemukan data terkait dengan alasan-alasan apa yang melatarbelakangi suatu ide atau sikap yang muncul. Data-data yang terakhir ini hanya mungkin didapat ketika peneliti misalnya melakukan wawancara mendalam atau diskusi terfokus.

- Penelitian kuantitatif menuntut kedewasaan subjek penelitian (responden) untuk mengisi alat penelitian/kuesioner dan melakukan pengukuran diri sendiri (self assesment) secara objektif. Berbeda dengan penelitian kualitatif di mana peneliti dapat segera melakukan intervensi dan pemeriksaan kritis ketika subjek penelitian diasumsikan tidak memberikan informasi yang tepat, dalam sebuah survei di mana kuesioner dibagikan dan responden mengisinya, seorang peneliti benar-benar mengandalkan kuesioner tersebut untuk mengolah serta mendapatkan data. Dalam pengalaman penulis, cukup banyak responden ketika mengisi kuesioner tidak terbiasa dan tidak membaca dengan baik petunjuk serta tujuan penelitian yang diharapkan. Misalnya ketika responden diharapkan untuk menuliskan sikap mereka secara pribadi atas suatu sikap religius tertentu, mereka justru berpikir untuk memperlihatkan pandangan normatif tentang apa yang seharusnya dan apa yang baik secara ideal. Belum lagi kita dapat menemukan di sana-sini sikap enggan dari responden terpilih untuk menilai secara detil dan teliti.

\section{PENUTUP}

Penulis berharap melalui kajian singkat ini kita mendapatkan gambaran bahwa metode kuantitatif dengan survei dan analisis statistik bukanlah hal yang sama sekali tidak dapat berkontribusi pada penelitian teologi praktis. Penelitian kuantitatif dalam kelemahan maupun kekuatannya dapat 
berkontribusi membantu teologi praktis untuk mendapatkan deskripsi-empiris atas pengalaman suatu komunitas religius. Penggunaan suatu metode dan pendekatan dalam penelitian lapangan harus dimulai dari kesadaran pada tujuan penelitian itu dan bentuk data apa yang dibutuhkan. Karena itu relevansi metode kuantitatif dalam penelitian teologi praktis ini harus kembali lagi pada tujuan, persoalan penelitian, dan perspektif teologis yang hendak dibangun.

\section{Catatan}

${ }^{1}$ Bagian awal karangan ini ditulis kembali dari Handi Hadiwitanto, "Teologi Praktis-Empiris, Pembangunan Jemaaat dan Relevansi Pemikiran Emanuel Gerrit Singgih", dalam Victor Hamel dkk. (eds.), Gerrit Singgih: Sang Guru dari Labuang Baji, Jakarta: BPK Gunung Mulia, 2010. Versi awal karangan ini telah dipresentasi dalam Studi Institut Persetia, 28 November 2012, di Fakultas Teologi UKIT Tomohon. Pada saat ini karangan ini telah disempurnakan untuk kepentingan publikasi di Jurnal Teologika Gema Duta Wacana.

2 Meskipun van der Ven $(1993 ; 2002)$ tidak secara khusus menekankan persoalan metode tertentu tetapi dalam uraiannya tentang lingkaran empiris nampak kuat bahwa ia berasumsi tentang metode kuantitatif sebagai pendekatan yang digunakan dalam operasionalisasi teori (1993: 134-139).

${ }^{3}$ Lingkaran empiris dapat dikatakan memiliki kesamaan ide dengan lingkaran pastoral (band. Henriot, 2005), di mana berteologi dilakukan dengan berangkat dari pemahaman atas masalah di tengah masyarakat (induktif). Lingkaran empiris memberikan perhatian lebih detil pada penyusunan alat penelitian dan prosedural analisis yang akan dilakukan.

${ }^{4}$ Dalam metode dan pengumpulan data yang bersifat kuantitatif, peneliti akan melakukan survei dengan sistem random dan sampling. Dasar pemikiran sebuah survei adalah seorang peneliti akan mendapatkan gambaran tentang suatu situasi praktis dalam satu populasi tertentu. Dengan kata lain, survei dalam metode kuantitatif membantu peneliti mendapatkan generalisasi karakter suatu populasi. Tetapi tentu harus diakui bahwa keunikan dari setiap individu dan perbedaan-perbedaan makna tidak dapat diperiksa secara mendalam, dan memang sejak awal hal ini tidak menjadi tujuan survei dalam metode kuantitatif. Penelitian kualitatif lebih memberikan masukan terhadap kekayaan dan keunikan karakter serta makna dari setiap informan yang terlibat. Tetapi tentu jumlah informan dan keluasan wilayah yang diteliti lebih terbatas. Konsekuensinya, peneliti harus bijaksana dalam menempatkan hasil penelitian pada konteks yang lebih besar.

${ }^{5}$ Hal yang dilihat oleh Singgih (2009: 61, 64) sebagai kesalahan umum dalam memahami kedua metode ini adalah asumsi bahwa yang satu lebih objektif dari yang lain, dan seolah-olah subjektivitas itu mutlak harus ditiadakan. Padahal yang benar adalah, objektivitas itu dapat terwujud selama subjektivitas yang kita miliki disadari, apa pun pendekatannya.

${ }^{6}$ Prof. Huber mempresentasikan skema ini dalam International Society of Empirical Research in Theology (ISERT)-Conference di Nijmegen, Belanda, April 2012.

\section{DAFTAR PUSTAKA}

David, Fely. 2005. Understanding and Doing Research: A Handbook for Beginners, Iloilo City: Social Science Research Institute, Central Philippine University. 
Field, Andy. 2005. Discovering Statistics Using SPSS (Second Edition), London: Sage Publications. Hadiwitanto, Handi. 2010. "Teologi Praktis-Empiris, Pembangunan Jemaat, dan Relevansi Pemikiran Pdt. Prof. E. Gerrit Singgih, Ph.D.”, dalam Victor Hamel dkk. (eds.), Gerrit Singgih Sang Guru dari Labuang Baji, Jakarta: BPK Gunung Mulia. .2016. Religion and Generalised Trust: An Empirical-Theological Study among University Students in Indonesia, Zürich: Lit Verlag.

Henriot, Peter. 2005. "Social Discernment and the Pastoral Circle", dalam Frans Wijsen, Peter Henriot, dan Rodrigo Mejía (eds.), The Pastoral Circle Revisited, New York: Orbis Books. Hermans, Chris A.M. 2004. "When Theology Goes 'Practical': From Applied to Empirical Theology", dalam C.A.M. Hermans, dan Mary E. Moore (eds.), Hermeneutics and Empirical Research in Practical Theology, Brill, Leiden, Boston.

Huber, Stefan. 2009. "Religion Monitor 2008: Structuring Principles, Operational Constructs, Interpretive Strategies", dalam Bertelsmann Stiftung (ed.), What the World Believes: Analysis and Commentary on the Religion Monitor 2008, Gütersloh: Verlag Bertelsmann Stiftung.

Osmer, Richard R. 2008. Practical Theology: An Introduction, Grand Rapids, Michigan: William B. Eerdmans Publishing Co.

Pennings, Paul; Hans Kemans; dan Jan Kleinnijenhuis. 2006. Doing Research in Political Science: An Introduction to Comparative Methods and Statistics (Second Edition), London: Sage Publications.

Singgih, E. Gerrit. 2005. "Punishment and Liberation: How the Pastoral Circle Transfomrs Our Theologies", dalam Frans Wijsen dkk., The Pastoral Circle Revisited, Maryknoll, New York: Orbis Books.

Te Grotenhuis, Manfred dan Theo van der Weegen. 2009. Statistical Tools: An Overview of Common Applications in Social Sciences, van Gorcum, Assen.

Van der Ven, Johannes. 1993. Practical Theology: An Empirical Approach, Pharos, Kampen. . 2002. "An Empirical or a Normative Approach to Practical-Theological Research? A False Dilema", Journal of Empirical Theology, Vol 2.

Verschuren, Piet dan Hans Doorewaard. 1999. Designing a Research Project, Lemma, Utrecht. Ziebertz, Hans-Georg. 2004. "Empirical Methodology and Normativity", dalam J.A. van der Ven dan Michael Scherer-Rath (eds.), Normativity and Empirical Research in Theology, Boston: Brill, Leiden. 